\title{
Norm or Necessity?
}

The Non-Interference Principle in ASEAN

Tram-Anh Nguyen is an undergraduate at Princeton University, majoring in Political Science with Certificates in East Asian Studies and Political Economy.

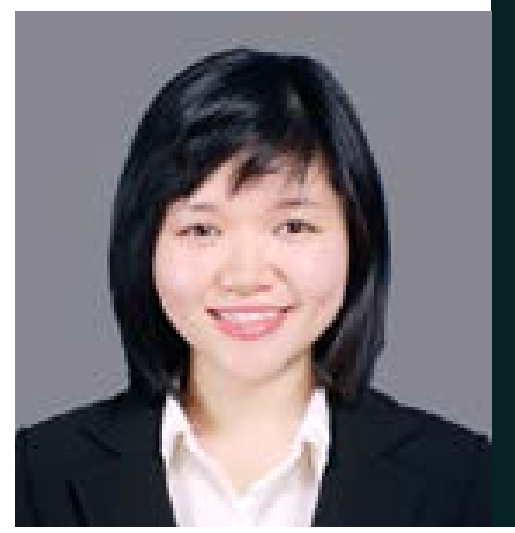

Founded in 1967, the Association of Southeast Asian Nations (ASEAN) is one of the most prominent intergovernmental organizations in Asia. ASEAN's main achievement has been to unite ten countries in Southeast Asia through shared goals of regional peace and prosperity. It attributes this success to the "ASEAN Way", of which the principle of non-interference is an integral part. ${ }^{1}$ Singapore's former Foreign Minister, Shunmugam Jayakumar asserted in 1997 that ASEAN's principle of non-interference in countries' domestic affairs had been "the key factor as to why no military conflict had broken out between any two member states since 1967."' Since 1997, however, countries outside the region have blamed the non-interference doctrine for ASEAN's ineffectiveness in dealing with regional problems. ${ }^{3}$ Calls for the adjustment and even abandonment of this norm have been voiced inside and outside the association, but ASEAN has kept the non-interference principle at the core of its diplomacy. In its first charter, signed in 2007, non-interference was retained as ASEAN's bedrock principle despite recommendations it be adjusted by a high-level advisory group of ASEAN's elder statesmen. ${ }^{4}$

This paper evaluates the importance of the non-interference principle in ASEAN and explains the group's steadfast adherence to it. Although ASEAN has never provided an official definition of this principle, in this paper interference is identified as ASEAN's deliberate attempts to influence the outcome of a conflict in a country without the consent of its government. Based on ASEAN's activities from 1997 to 2007, the paper argues that the non-interference principle does not actually impact ASEAN's decisionmaking about whether to interfere in a domestic conflict. However, the organization retains the principle primarily because it gives nondemocratic members of ASEAN confidence in their immunity to external intervention.

\section{Literature Review}

Although ASEAN has never defined the non-interference norm, the organization's key documents and references show that the norm means protection of its members' Westphalian sovereignty. Krasner (1999) defined Westphalian sovereignty as "an institutional arrangement for organizing political life that is based on two principles: territoriality and the exclusion of external actors from domestic authority structures." ${ }^{15}$ The non-interference norm requires that ASEAN refrain both from criticizing member governments' actions towards their own citizens and from making the domestic 
political system of states and the political styles of governments a basis for deciding their membership in ASEAN. ${ }^{6}$

Krasner also discusses two logics of action in international affairs: a logic of expected consequences and a logic of appropriateness. ${ }^{7}$ A logic of expected consequences views "political action and outcomes, including institutions, as the product of rational calculating behavior designed to maximize a given set of unexplained preferences." ${ }^{\text {"8 }}$ A logic of appropriateness sees "political action as a product of rules, roles, and identities that stipulate appropriate behavior in given situations." ${ }^{9}$ The debate over ASEAN's non-interference principle centers on the question of whether its adoption follows a logic of expected consequences or a logic of appropriateness. In other words, scholars still disagree whether ASEAN adheres to the principle because of its practical benefits or because of its virtues.

Acharya (2009) argues that a logic of appropriateness drove ASEAN's founding states to adopt the non-interference principle, although he acknowledges this decision was also partly due to their concerns about regime security and internal stability under threat of communist subversion. ${ }^{10}$ Given the Southeast Asian states' diversity with regard to size, economic development, ethnicity, socio-cultural heritage and history, ASEAN's founders needed appropriate codes of conduct and norms to help ASEAN countries unite and foster a peaceful political environment. ${ }^{11}$ In particular, the principle of non-interference "played a crucial role in molding this interaction and compromise" among ASEAN countries. ${ }^{12}$ As non-interference has become "part of the ASEAN identity," ASEAN has adhered to it fairly consistently, even though it inhibited the organization from reacting effectively to regional political crises. ${ }^{13}$ Many scholarly works assume that ASEAN's non-interference principle is indeed sacrosanct. ${ }^{14}$

However, a logic of appropriateness cannot explain why ASEAN intervened in the domestic affairs of Cambodia in 1997 or those of Myanmar after 2003. Those aforementioned scholars merely dismiss these cases as exceptions in an otherwise consistent pattern of ASEAN noninterference. They fail to recognize that these were the only post-Cold War political conflicts that occurred in small and weak Southeast Asian states, while all the ones that ASEAN remained silent about related directly to big regional players.

In contrast, other scholars adopt a realist perspective and explain ASEAN's noninterference principle based on a logic of consequences. ${ }^{15}$ According to this view, ASEAN countries stick to the noninterference principle because it protects member states with illiberal regimes. It can be relaxed on occasion to soothe international criticisms of ASEAN inaction, but overall, the organization's concern for regime security is predominant. ${ }^{16}$ Khoo and Jones highlight cases where ASEAN countries have interfered in others' internal affairs to argue that the non-interference principle is applied flexibly to best serve certain states' interests. ${ }^{17}$ However, these scholars' focus on the instances where ASEAN violated its non-interference principle (termed "violation cases" hereafter) overlooks those where it did not (termed "non-violation cases" hereafter). They fail to completely rule out the possibility that these interventions were just exceptions to ASEAN's norm of non-interference.

Overall, existing scholarship fails to offer a systematic analysis of ASEAN's responses to political and security conflicts in the region and their implications for understanding 
the non-interference principle. Instead, they only provide disconnected examples and anecdotes to support their arguments. This method also makes it difficult to identify patterns in ASEAN's adherence to the noninterference principle over time and across cases.

\section{Assessing ASEAN's non-} interference: logic of consequences or logic of appropriateness?

To evaluate ASEAN's adherence to the non-interference norm and its motivations, this paper examines a decade of the organization's responses to prominent internal political-security conflicts. The timeframe for my analysis begins in 1997, when criticisms of the non-interference principle first appeared, and ends in 2007, when ASEAN decided to formalize the principle in its charter. ${ }^{18}$ Although politicalsecurity conflicts are not the only realm where the non-interference principle is applicable, they are most directly related to governments' concerns about regime security and stability, which many realists argue is the reason for ASEAN's attachment to the principle. The list of conflicts is drawn fro the UCDP/PRIO Armed Conflict Dataset, scholarly articles, and news reports from the NewsBank database. The information on ASEAN's responses is taken from official statements on the ASEAN Secretariat's website and reports in domestic and international media. ASEAN's intervention is defined as its deliberate attempts to influence the outcome of a conflict in a country without the consent of its government. Table 1 presents the conflicts, the parties involved, and whether ASEAN intervened or not.i, iii

\section{Table 1: Political-Security Conflicts In Southeast Asia 1997-2007}

\begin{tabular}{|c|c|c|c|c|}
\hline Case & Cosflict & Year & Conflict parties & $\begin{array}{l}\text { ASE AN } \\
\text { inicrventian? }\end{array}$ \\
\hline 1 & $\begin{array}{l}\text { Cambodian covelp } \\
\text { déas }\end{array}$ & 1907 & $\begin{array}{l}\text { CPP (led by Hun Sen) vs. } \\
\text { FUNCINPEC (led by } \\
\text { Norodom Kanariddh) }\end{array}$ & Yes \\
\hline 2 & $\begin{array}{l}\text { Philippines-Mindinan } \\
\text { confliti }\end{array}$ & $1997-2007$ & $\begin{array}{l}\text { Sinvernment of Philippines } \\
\text { w. Musliun selel groups } \\
\text { (MILF. MNIF_ASG) }\end{array}$ & No \\
\hline 3 & $\begin{array}{l}\text { Polisieal perswoution } \\
\text { of former Malaysian } \\
\text { Deputy PM Anwar } \\
\text { locahim }\end{array}$ & 1998 & $\begin{array}{l}\text { Gowernmont of Malaysia vs, } \\
\text { Anwar lbrahim }\end{array}$ & No \\
\hline 4 & $\begin{array}{l}\text { Inourgecsy in Acch, } \\
\text { Indocesili }\end{array}$ & 1999.2005 & $\begin{array}{l}\text { Goverimicmt of Indoncsia ws. } \\
\text { Free Aceh Mfovement (GAM) }\end{array}$ & Nio \\
\hline 5 & Bast Tmoncse crisis" & 1499 & $\begin{array}{l}\text { Govemmint of Indoncia W. } \\
\text { East Timotese }\end{array}$ & No \\
\hline 6 & $\begin{array}{l}\text { Myanmat's } \\
\text { parpression of the } \\
\text { pro-democracy } \\
\text { movement }\end{array}$ & $\begin{array}{l}1997- \\
2007 \text {; } \\
\text { Aung San } \\
\text { Suu Kyi's } \\
\text { arrest } \\
\text { (20000- } \\
20002 \\
2003-3007)\end{array}$ & $\begin{array}{l}\text { Military gowemmeni vs } \\
\text { National } 1 \text { eague for } \\
\text { Democrasy (NL.D lod by } \\
\text { Aung San Suu Kyil }\end{array}$ & Yes \\
\hline 7 & $\begin{array}{l}\text { South Thailand } \\
\text { insurbency }\end{array}$ & $\begin{array}{l}2003-2007 \\
\text { Tak Dai } \\
\text { Incisken } \\
(2004)\end{array}$ & $\begin{array}{l}\text { Gowemmont of Thailand vs. } \\
\text { Patani insurgents }\end{array}$ & No \\
\hline 8 & Thai creep detan & 20006 & $\begin{array}{l}\text { Royal Thai Amry vs. PM } \\
\text { Thalsin Shinawatra }\end{array}$ & No \\
\hline
\end{tabular}




\section{These two cases of ASEAN interference in the domestic affairs of Myanmar and Cambodia suggest a double standard in adherence to the non-interference principle}

During these ten years, ASEAN only intervened in two cases: the coup in Cambodia (1997) and the political persecution of Aung San Suu Kyi in Myanmar (cases 1 and 6). It is tempting to conclude that these cases are only rare exceptions to the norm. However, closer examination reveals that all cases of non-interference are related directly to the founding members of ASEAN - Thailand (case 7 and 8), Indonesia (case 4 and 5), the Philippines (case 2) and Malaysia (case 3). These countries are also the most advanced economies in the region. In 2002, for instance, Indonesia's GDP comprised $30 \%$ of the region's total GDP and was the biggest ASEAN economy. ${ }^{19}$ Thailand was the second biggest with 19.5\% of ASEAN's total GDP, while Malaysia and the Philippines contributed $15.5 \%$ and $12.5 \%$ of ASEAN's total GDP respectively. In contrast, Cambodia and Myanmar were among the poorest countries in the region. In 2002, Myanmar's GDP was only $1.2 \%$ of ASEAN's total GDP while Cambodia was the second poorest state with only $0.66 \%$ of ASEAN's total GDP. Moreover, both Myanmar and Cambodia were relatively new members of ASEAN; Cambodia was still applying for the membership when the coup happened.

These two cases of ASEAN interference in the domestic affairs of Myanmar and Cambodia suggest a double standard in adherence to the non-interference principle: the organization upholds the principle whenever conflicts occur within its powerful members (Thailand, Indonesia, the Philippines, Singapore and Malaysia) are primary parties, but can interfere when they involve its poorer and weaker members. To further assess and analyze this pattern, the following sections examine the two cases of norm violation and then discuss the non-violation ones.

\section{Violation Case \#1: Cambodia}

In July 1997, Second Prime Minister Hun Sen of the Cambodian People's Party (CPP) ousted the First Prime Minister Norodom Ranaridh of the Royalist Party (FUNCINPEC) in national elections. This broke the twoprime-minister government system arranged after the UN-supervised election in 1993. ${ }^{20}$ The event happened while Cambodia was in the process of applying for ASEAN membership. When the crisis hit, ASEAN initially denied that this internal conflict would affect its decision about whether to admit Cambodia as a member state. ${ }^{21}$ This was in line with its non-interference principle; according to the principle, ASEAN should not use the domestic political system of a country as grounds to decide its admission into ASEAN. ${ }^{22}$

However, ASEAN's attitude changed after its major trading partners - the United States, the European Union and Japan - all pressured it to use its economic leverage to solve the political crisis in Cambodia. ${ }^{23}$ ASEAN's foreign ministers announced after their ministerial meeting in July 1997 that they had decided to delay Cambodia's entry into ASEAN indefinitely. ${ }^{24}$ In addition, ASEAN sent a delegation consisting of the Indonesian, Thai, and Philippine Foreign Ministers to Cambodia to mediate a settlement. ${ }^{25}$ 


\section{Violation Case \#2: Myanmar}

A military dictatorship took over the government of Myanmar in 1989.26 The junta refused to convene the parliament and transfer power to the National League for Democracy (NLD), led by Aung San Suu Kyi, despite the NLD's landslide victory in the 1990 national election. Aung San Suu Kyi was placed under house arrest from 1989 to 1995, and then again from 2000 to 2002, and 2003 to 2007.

Unlike Cambodia, Myanmar was admitted into ASEAN in 1997 despite strong objections by the US and EU due to Myanmar's poor human rights and democracy record. ${ }^{27}$ With abundant natural resources, Myanmar was a potential engine of economic growth for ASEAN. ${ }^{28}$ ASEAN did not want to delay Myanmar's entry into ASEAN because it worried that Myanmar might get closer to China as a result. ${ }^{29}$ ASEAN justified its admission of Myanmar with the concept of "constructive engagement", promising to encourage political liberalization in Myanmar by helping it develop its economy. ${ }^{30}$ This "constructive engagement", however, proved unsuccessful when the military junta in Myanmar put Aung San Suu Kyi under house arrest for the third time in 2003. After this, the Western powers put more pressure on ASEAN to resolve the issue. The EU boycotted any meeting or cooperation project with ASEAN that Myanmar participated in. ${ }^{31}$ Washington also stalled free-trade talks with ASEAN to signal its disapproval of Myanmar's political behavior. Consequently, ASEAN ministers, for the first time, jointly urged Myanmar to release Aung San Suu Kyi and NLD members. ${ }^{32}$ In 2004 , with no progress toward democratization in
Myanmar, the US and some EU members, led by the UK, threatened not to attend the 2006 ASEAN Summit chaired by Myanmar unless Myanmar released Ms. Suu Kyi from house arrest. ${ }^{33}$ Powerful ASEAN members such as Malaysia, Singapore and Indonesia pressured Myanmar to relinquish its position as chair. ${ }^{34}$ Arguing that Myanmar's internal affairs carried "implications for the region," ASEAN continued to break the noninterference norm to push for quicker political reforms. ${ }^{35}$ It sent an envoy headed by the Malaysian Foreign Minister to Myanmar in 2006 to examine Myanmar's progress in improving its human rights conditions. ${ }^{36}$ ASEAN also publicly urged Myanmar to speed up political reforms and demanded tangible results in what amounted to the strongest statement ASEAN has ever made about the domestic politics of one of its member states. ${ }^{37}$ When Myanmar's military government suppressed a protest by Buddhist monks, ASEAN foreign ministers openly expressed their horror and urged the junta to exercise restraint. ${ }^{38}$

Although the conflicts in Myanmar and Cambodia differed in nature and length, ASEAN received tremendous international pressure in both cases to intervene, especially for Myanmar. One can argue that because both countries have abundant natural resources and border many ASEAN countries, ASEAN was particularly concerned about their stability. Nevertheless, ASEAN was reluctant to break the non-interference principle in both cases before it came under significant pressure from its top trade partners. This suggests that international pressure, in addition to the relative power of the states involved, is an important factor

\section{Although the conflicts in Myanmar and Cambodia differed in nature and length, ASEAN received tremendous international pressure in both cases to intervene, especially for Myanmar.}




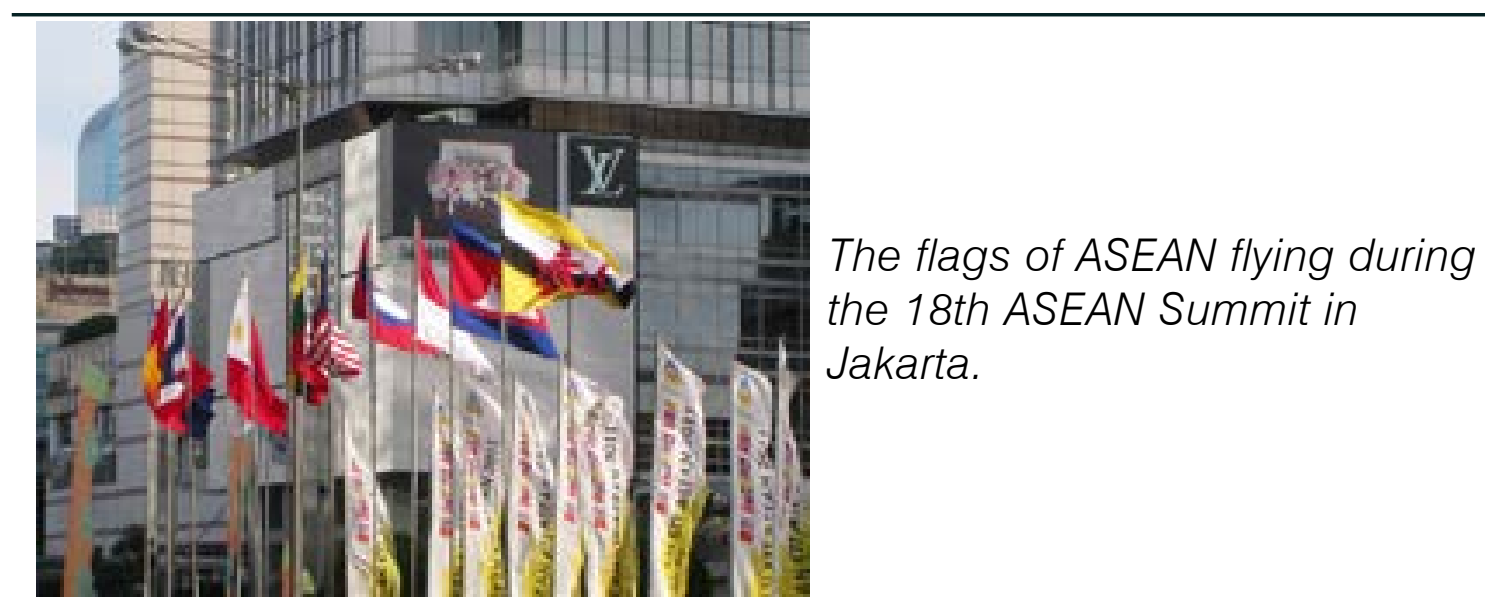

in these cases. However, as the following sections show, when ASEAN's powerful members are directly involved, even international pressure cannot force ASEAN to break its golden rule of non-interference.

\section{The Non-Interference Principle Upheld}

To examine the effectiveness of a norm, one not only needs to look for violations, but also to evaluate whether actors would still behave in the same way without the norm. ${ }^{39}$ I argue that the involvement of powerful states, not the non-interference principle, was the reason why ASEAN refused to interfere in the non-violation cases.

The East Timorese crisis is a telling example. East Timor was Indonesia's colony for more than 30 years. In 1998, in a referendum organized by UN peacekeeping forces, 79.5 percent of East Timorese voted for independence from Indonesia. ${ }^{40}$ Immediately after that, the pro-Indonesian Timorese militia, armed by the Indonesian army, killed approximately 1,200 civilians in East Timor. ${ }^{41}$ Similar to the conflicts in Cambodia and Myanmar, the East Timorese crisis also attracted much international attention. Its timing (1999) was close to that of Cambodia's coup and was during the period when ASEAN was trying to shore up its standing after the Asian Financial crisis.
However, although the Security Council and the US urged ASEAN to persuade Indonesia to accept external intervention, ASEAN insisted that East Timor was Indonesia's internal affair and maintained the noninterference principle. ${ }^{42}$ The organization also avoided discussing East Timor in their meetings. ${ }^{43}$ Only when Indonesia explicitly consented to UN peacekeeping and requested ASEAN countries' participation in these peacekeeping forces did ASEAN members collaborate with the UN. ${ }^{44}$

Considering that ASEAN interfered in Cambodia and Myanmar's domestic affairs despite initial protests by those two countries' governments, ASEAN's sensitivity to Indonesia's reaction can only be understood in terms of Indonesia's importance in the organization. Not only is Indonesia one of ASEAN's founders, it is also the largest country in Southeast Asia and had the highest GDP in the region in 1999. ${ }^{45}$ Therefore, ASEAN countries had strong incentives to avoid offending this nation. ASEAN's deference toward Indonesia was apparent even before the crisis. The organization stood by when Indonesia's invasion of East Timor was raised in 1976 at the UN General Assembly. ${ }^{46}$

Given that ASEAN refused to offend Indonesia despite tremendous international pressure, 


\section{It is no surprise that ASEAN remained silent regarding the conflicts in Mindanao (Philippines), Aceh (Indonesia), southern Thailand, the political persecution of a former Malaysian deputy prime minister, and the 2006 coup in Thailand.}

it is no surprise that ASEAN remained silent regarding the conflicts in Mindanao (Philippines), Aceh (Indonesia), southern Thailand, the political persecution of a former Malaysian deputy prime minister, and the 2006 coup in Thailand. All of these conflicts not only directly involved powerful ASEAN states (Thailand, Indonesia, the Philippines and Malaysia) but also generated relatively lesser international pressure on ASEAN. Moreover, as the list of conflicts shows, most of ASEAN's powerful states had to deal with separatism and ethnic tensions in their territories. Thus, it is only logical that they would resist ASEAN's involvement in ethnic conflicts (cases 2, 4, 5 and 7), because they did not want to establish a precedent that would allow future ASEAN inference in their own ethnic conflicts. ${ }^{47}$

Therefore, even without the non-interference norm, ASEAN would still not have intervened in the non-violation cases, because it feared offending its most powerful members. Together with the two cases of violation in Cambodia and Myanmar, this conclusion strongly suggests that the non-interference norm does not decide whether ASEAN intervenes in a conflict or not. The question, then, is why ASEAN would still kep the noninterference principle.

\section{Reasons for Retaining the Non- Interference Principle}

To understand why ASEAN insisted on keeping the non-interference principle in its 2007 Charter, even though the norm itself does not determine ASEAN's pattern of interference, one must understand the value of this principle to ASEAN member states. Realist scholars like Haacke and Jones have incorrectly assumed that all ASEAN member states value the non-interference principle for protecting their sovereignty. However, the ten ASEAN countries have very different political systems, interests and priorities, and thus different valuations of this principle. Therefore, they have different levels of resistance toward changes to the non-interference norm. An examination of ASEAN members' diverse reactions toward challenges to the non-interference principle illuminates their attitudes.

How much an ASEAN country resists changing the non-interference principle depends on how confident it is of its immunity to future ASEAN interference in the absence of the non-interference principle. I argue that this confidence (called "Confidence" hereafter) depends on two factors: the country's level of democratization and its relative power in the region. The more democratic a state is, the more legitimacy the government has and the less it worries that ASEAN would come under international pressure to interfere in its domestic affairs on the grounds of supporting human rights or democracy. On the other hand, the more relative power an ASEAN country has, the less other member states wish to offend this country and damage their relations with it.

To illustrate this point, I create a Confidence scale from 0 to 1 to measure ASEAN members' confidence that their sovereignty 
will not come under threat even without the non-interference principle. Each country's score is the weighted sum of its level of democratization (calculated from its Freedom House score ${ }^{i v}$ ) and its relative power (a composite indicator estimated based on its GDP, population and military expenditures). Graph 1 shows the Confidence scores of all ASEAN countries in the period 1997-2007.

Based on these scores, ASEAN members can be divided into three groups. The first group with Confidence score less than 0.15 includes weaker and less democratic members of ASEAN, such as Myanmar, Laos, Brunei, and Vietnam. I predict that these countries would most resist any change to the non-interference norm, because they would be the most likely targets of future ASEAN intervention, given the undemocratic nature of their regimes and their limited relative power. The members of the second group, with Confidence scores ranging from 0.15 to 0.3 , are Malaysia, Singapore, Indonesia (before 1999) and Thailand (after 2005). These countries are major powers in ASEAN, but with relatively democratic regimes. Thus, they still want to keep the non-interference principle to protect their illiberal political system, but they are more flexible regarding its applications due to their confidence in their relative power. The last group with the highest Confidence score (above 0.3) includes all democratic countries in ASEAN: the Philippines, Indonesia (after 1999), and Thailand (before 2005). They are the most confident in their legitimacy because of their more democratic systems. Therefore, I predict they would be the strongest advocates for changes to the noninterference principle in ASEAN.

To test my hypotheses, I examine the diverse responses of ASEAN members to proposals and issues that challenged the noninterference principle between 1997 and 2007.
Because ASEAN exercises quiet diplomacy and holds private meetings, these responses can only be collected from foreign ministers' public statements and interviews with journalists. Therefore, one can only observe the reactions of countries with the strongest opinions regarding whether ASEAN should adhere or deviate from the non-interference principle. Table 2 (Challenges for the noninterference principle in ASEAN 1997-2007) represents cases when there were diverse opinions regarding the application of the non-interference principle, together with the strongest proponents and opponents of changes to the principle. Their Confidence scores are put in parentheses next to their names. For issues that lasted more than one year, the ranges of Confidence scores are reported instead of a single score.

The results in Table 2 fit my hypothesized expectations for the three groups, except for the highlighted cases of Indonesia and Thailand (which will be addressed in further detail later). Countries in Group 1 (with a Confidence score less than 0.15 ) persistently opposed any deviations from the noninterference principle. For them, the noninterference principle guarantees protection for their weaker and less democratic regimes. They are afraid that any small deviation from the principle will set a dangerous precedent for future ASEAN interference in domestic affairs.

Apart from the highlighted cases of Indonesia and Thailand, countries in Group 3 (with a Confidence score more than 0.3), with high Freedom House score and strong relative power, are the strongest proponents for changes to the non-interference principle. As these countries are democratic, their governments have to respond to their constituents and bear responsibility for the results of their foreign policies. Therefore, when international criticism of the non- 


\section{Graph 1: Confidence Scores of ASEAN countries (1997-2007)}

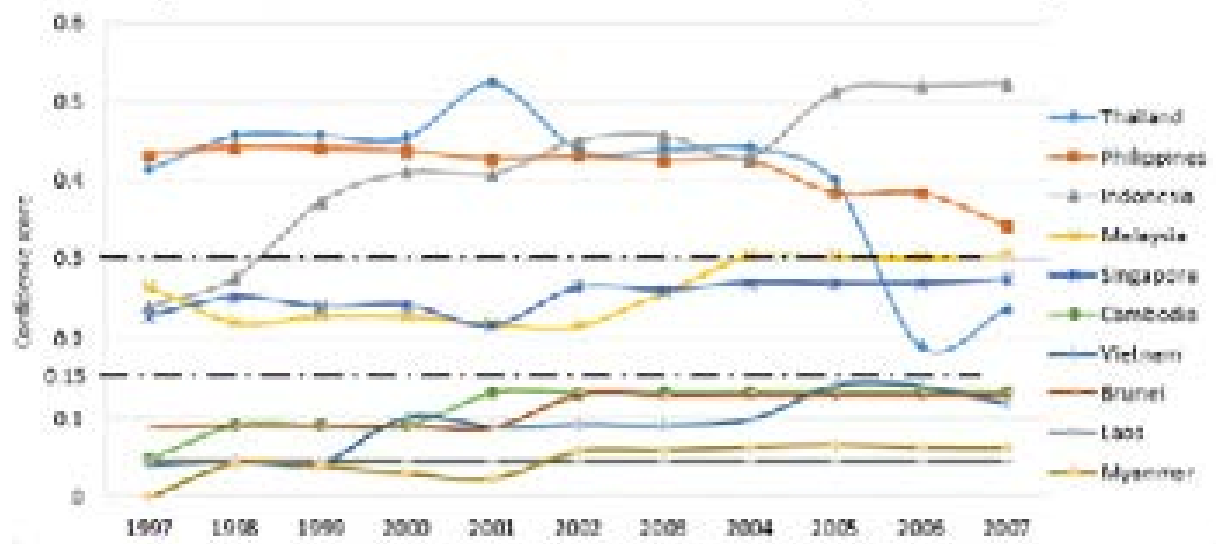

Table 1: Challenges for the Non-Interference Principle in ASEAN 1997-2007

\begin{tabular}{|c|c|c|c|c|}
\hline Cnses & beuca/ Dropecala & Year & $\begin{array}{l}\text { Adroentea for dovintion } \\
\text { from the norr } \\
\text { interference bnnciole }\end{array}$ & $\begin{array}{l}\text { Opponerts of } \\
\text { deviaton from the } \\
\text { ron interference } \\
\text { principte }\end{array}$ \\
\hline$t$ & 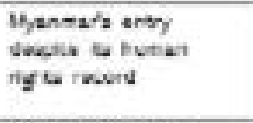 & $1 D E Z$ & 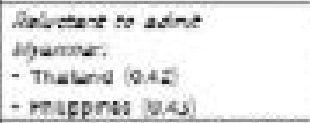 & 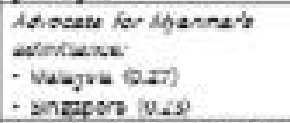 \\
\hline 2 & $\begin{array}{l}\text { Fotocramine of } \\
\text { Canbodat ortry } \\
\text { bacaute of tha coup }\end{array}$ & 2202 & 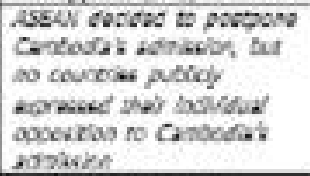 & 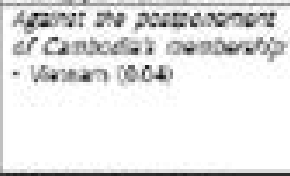 \\
\hline 8 & 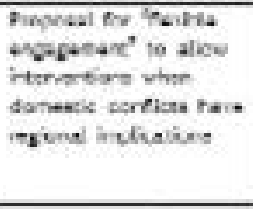 & $1008-4$ & 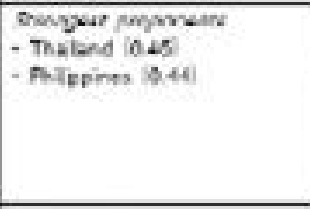 & 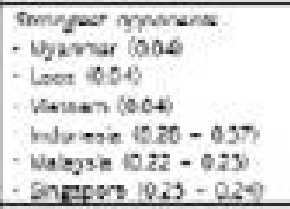 \\
\hline 4 & 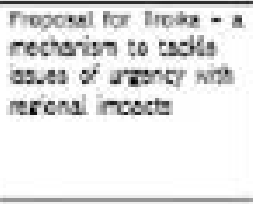 & $19 y$ & 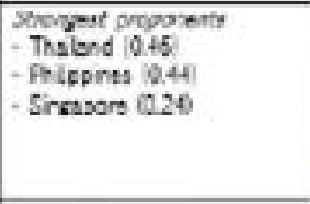 & 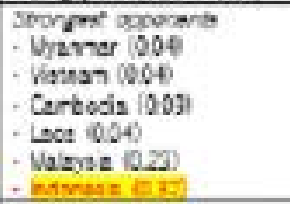 \\
\hline 5 & 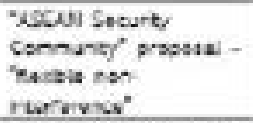 & 2000 & 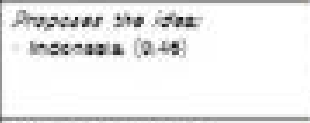 & 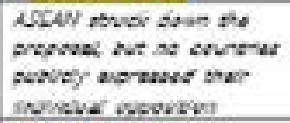 \\
\hline 0 & $\begin{array}{l}\text { roochal ror ao acroast } \\
\text { Anan peacacieprg } \\
\text { nore }\end{array}$ & SWOS & 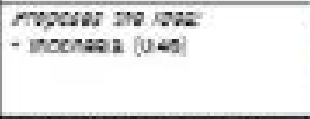 & 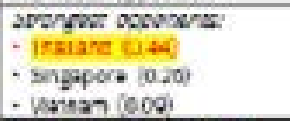 \\
\hline 7 & $\begin{array}{l}\text { Uyangak ariagt of } \\
\text { Aurg San Sua Kyi }\end{array}$ & $\begin{array}{l}2003- \\
2005\end{array}$ & 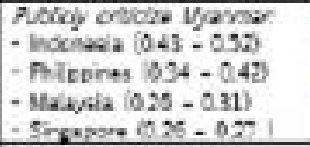 & 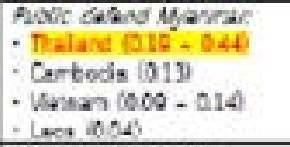 \\
\hline 2 & 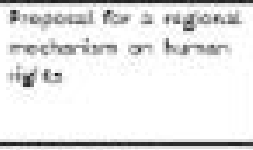 & $\begin{array}{l}3004 \\
2000\end{array}$ & 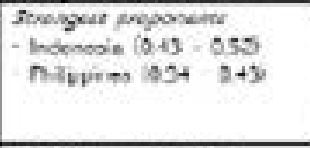 & 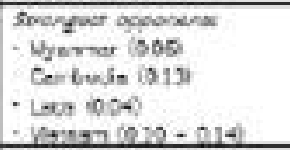 \\
\hline 9 & $\begin{array}{l}\text { Reverr of not } \\
\text { intersence errcipls in } \\
\text { the naw Urarter }\end{array}$ & $\begin{array}{l}20.0 \\
20.0\end{array}$ & 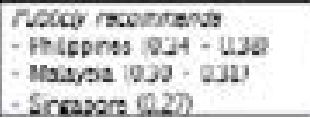 & 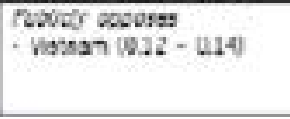 \\
\hline
\end{tabular}




\section{Activists gather to protest the detention of Aung San Suu Kyi.}

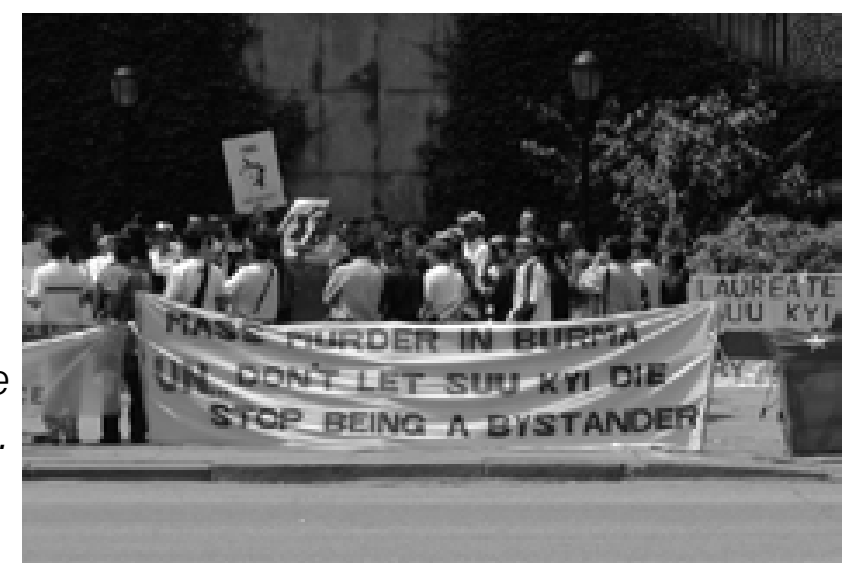

interference principle started to damage ASEAN's reputation, it also lowered these states' credibility and damaged relations with their major partners (the US, the EU, and Japan). Therefore, these democratic governments felt the need to change the non-interference principle and improve their images. Moreover, democratic countries often have strong civil society actors who oppose human rights abuses by their undemocratic ASEAN partners and demand actions from their democratic governments. For example, in 2004, the Philippines' parliamentarians pressured the government to oppose Myanmar becoming the chair of ASEAN in 2006 because of its continued detention of pro-democracy leader Aung San Suu Kyi. ${ }^{48}$ This also explains why all the proposals to change the interpretation of the non-interference principle came from democratic ASEAN members.

Countries in Group 2 (with a Confidence score more than 0.15 but less than 0.3 ) have the most inconsistent patterns of adherence to the non-interference principle. The countries in this group, Malaysia, Singapore, Indonesia (before 1999) and Thailand (after 2005), are concerned enough for their illiberal governments to want to maintain the existence of the non-interference principle. However, they are also confident enough in their relative power within ASEAN to deviate from the non-interference principle when the cost of upholding it exceeds its benefits. For instance, in 1998, Singapore strongly opposed Thailand's proposal for "flexible engagement" to loosen the principle of non-interference (case 3). However, in 1999, Singapore advocated for the Troika mechanism to respond to urgent internal issues that may have spillover effects in the region (case 4). Singapore's position was affected by its concern about the regional economic recovery and investors' confidence. Singapore's former Foreign Minister, S. Jayakumar, emphasized that "ASEAN faced a crisis of confidence."49 The international community had criticized ASEAN's non-interference principle for paralyzing the organization during the 1997 Asian Financial crisis. Singapore realized that unless ASEAN made some changes to the non-interference norm, its economy would suffer. Nevertheless, it still wished to maintain the non-interference principle to protect its own undemocratic government. Although the Troika mechanism was clearly a deviation from the non-interference principle, Jayakumar tried to argue that it should not be construed as "compromising sovereignty," but as "greater cooperation and pooling of our resources to deal with problems that countries cannot handle on their own separately but yet can affect the others." 50

Indonesia and Thailand provide the three observed instances of prediction outliers, 
suggesting the analytical limits of the Confidence score. When Indonesia's Confidence score was 0.37 , it still opposed the proposal for Troika in 1999. Indonesia's confidence score increased dramatically from 0.27 in 1998 to 0.37 in 1999 because Indonesia's nondemocratic President Suharto was forced to step down because of his failure to fix the problems of the financial crisis. Indonesia's Freedom House score changed immediately from 5 to 3.5. Although Suharto's successor, President B. J. Habibie, started to democratize the country in 1999, its transition into a full democracy was not complete until 2003. In the four years after Suharto stepped down, two presidents were ousted by the Indonesian parliament. ${ }^{51}$ With its unstable new democracy, Indonesia in 1999 was not yet ready for changes to ASEAN's non-interference principle. The Confidence score, which is strongly based on the Freedom House score, cannot pick up Indonesia's vulnerability during this transition from 1998 to 2003. Starting from 2003, Indonesia's behavior fits this paper's prediction well. It tirelessly advocated for a reinterpretation of the non-interference principle with proposals for ASEAN Security Community (case 5), a Southeast Asian peacekeeping force (case 6), and an ASEAN human rights mechanism (case 8).

Thailand's behavior in 2003 and 2004 also deviates from the prediction based on the Confidence score. This result is also due to the insensitivity of the Freedom House scores. Although Prime Minister Thaksin Shinawatra was democratically elected in 2001, he was not a liberal leader. Under his harsh policies, Thailand's human rights record worsened. His 2003 police crackdown on drug-trafficking caused the deaths of an estimated 2,200 suspects. ${ }^{52}$ His suppression of Muslim separatists in southern Thailand led to the infamous Tak Bai incident in 2004, when 87 protestors died of suffocation after they were packed into military trucks. ${ }^{53}$ Thaksin kept using the non-interference principle to prevent discussions of these incidents in ASEAN. He threatened to walk out of the ASEAN Summit in 2004 if anyone mentioned the Tak Bai incident. ${ }^{54}$ Therefore, even though technically Thailand was still a democratic country in 2003 and 2004 (and thus its Freedom House score was still 2.5), its government started to need the protection of the non-interference principle to shield its human rights abuses from criticism.

By examining individual ASEAN members' attitude toward the non-interference norm, one can clearly see that the strongest supporters of ASEAN's strict adherence to the non-interference principle are weaker, less democratic countries. The more democratic a country is, and the more relative power it has within ASEAN, the less it needs the non-interference norm. However, because relative power is relative - that is, an increase in country A's power causes a decrease in that of other countries - it is not possible to mitigate its influence on a country's stance regarding the non-interference principle. Only democratization is likely to prompt ASEAN to change this principle. Indonesia, for instance, transformed from a staunch protector of the non-interference principle into the most active advocate for its modification after its own democratization. Thus, as long as there are still few democratic countries in ASEAN, the non-interference norm is still likely to remain.

\section{The more democratic a country is, and the more relative power it has within ASEAN, the less it needs the non-interference norm.}




\section{Conclusion}

This paper has evaluated the importance of the non-interference principle in ASEAN and has explained its members' steadfast loyalty to it by examining the organization's actions from 1997 to 2007. Analyzing cases of violation and non-violation of the noninterference principle, it provides strong evidence that the non-interference principle has not determined whether ASEAN interferes in a domestic conflict or not. To explain ASEAN's attachment to the non-interference principle, I created a novel Confidence (of immunity) index and examined individual ASEAN members' responses to proposed challenges to the principle during this decade. The results demonstrate that the greater a state's level of democratization and relative power, the more confident it is of its immunity to future ASEAN interference and thus the less it insists on the continued existence of the non-interference principle in ASEAN. However, as relative power is relative, the main reason why ASEAN still retains the non-interference principle is because its democratic members are a minority. ASEAN's non-democratic members need the principle to give them confidence in their immunity to external intervention. Therefore, a logic of consequences best accounts for ASEAN's behavior regarding the non-interference principle. 